\title{
Research on Optimal Allocation Strategy of Bank Credit Funds Based on KMV Model and Logit Model
}

\author{
Chao Liu", Xiaofan Zhang, Yuerong Wang \\ Anhui University of Finance \& Economics, Bengbu 233030, Anhui province, China. E-mail: 2898592158@qq.com
}

\begin{abstract}
Using KMV model, normal Copula function, K-means cluster analysis and logit model, this paper constructs the enterprise credit risk assessment model, bank credit fund optimal allocation model, banking risk index system, and synthetically uses software such as MATLAB、SPSS to solve the problem of credit fund distribution strategy for small and medium-sized enterprises, and draws the conclusion that the loan interest rate classification of enterprise credit risk assessment, the weight of bank to credit fund distribution, and the change of bank risk index weight in sudden situation. Finally, the above model provides the strategy for bank credit fund allocation and gives the test and evaluation.

The outstanding features of this paper are: using the KMV model and the normal Copula function, combining the enterprise credit rating and default times to establish a linear model to quantify the enterprise credit risk, will not be easy to calculate the industry violation probability quantitative analysis, also get the bank credit annual interest rate for different industries and levels of enterprises, and through the representative industries of the optimal loan weight calculation, so that the bank decision has the characteristics of the least unit risk. This paper also establishes a banking risk index system with emergency factors, which is of practical significance to make decision analysis of emergency events.
\end{abstract}

Keywords: KMV Model; Logit Model; Optimal Allocation of Credit Funds

\section{Background}

\subsection{Background introduction}

In the development of the whole enterprise, the small and medium-sized enterprises are an indispensable part of the market development and an important part of the national economy. In most cases, MSMEs often choose to borrow from banks as a means of financing. For commercial banks, the risk of borrowing is closely related to the object of borrowing. Banks usually provide loans to strong, stable supply and demand enterprises based on credit policy, business transaction bill information and the influence of upstream and downstream enterprises, and can give interest rate concessions to enterprises with high reputation and low credit risk. Banks will first assess the credit risk of small and medium-sized enterprises according to their strength and reputation, and then determine whether to lend and credit strategies such as loan line, interest rate and term based on credit risk and other factors. Small and medium-sized enterprises want to break through the problem of financing difficulties and expensive financing, the social system and financial institutions to provide help is essential.

\subsection{Research significance}

\subsubsection{Improved management of credit risk}

\footnotetext{
Copyright (C) 2021 Chao Liu et al.

doi: 10.18686/fm.v6i1.3061

This is an open-access article distributed under the terms of the Creative Commons Attribution Non-Commercial License

(http://creativecommons.org/licenses/by-nc/4.0/), which permits unrestricted non-commercial use, distribution, and reproduction in any medium, provided the original work is properly cited.
} 
The credit risk of financial institutions can be fully identified by determining whether to lend according to credit risk and other factors, such as loan quota, interest rate and term, and by analyzing the relevant situation and possible problems of bank enterprise loans, the corresponding measures are put forward.

\subsubsection{Helps to reduce the bank's loan failure rate}

It helps banks to evaluate the risks of related enterprises reasonably and enhances the possibility of successful financing, which is conducive to promoting the economic development of local areas. It provides ideas for other financial institutions to solve the credit risk of enterprises, and also helps financial institutions to evaluate the credit risk of enterprises more accurately and reduce the loss of non-performing loans.

\section{Literature review}

Literature ${ }^{[1]}$ Chi Thailand, Zhang Yajing and others, first select the index system according to the default state ability, establish the small enterprise debt credit rating system, then solve the equation between the default state variable and probit evaluation index, and determine the index selected twice. Probability theory and linear difference equations to coal market price forecasting.

Literature $^{[2]}$ Cao Yong, Li Menggang and others first applied the KMV model to calculate the default probability according to the industry average stock price, industry average debt and other data. Secondly, the normal Copula function is used to calculate the joint probability of default state and the difference coefficient of bank credit funds. Finally, the optimal allocation model is established.

Literature $^{[3]} \mathrm{Yu}$ Desheng, Li Xing, based on the data of listed companies in a certain industry, first selects 14 evaluation indexes representing credit risk. Secondly, four important variables are obtained by using logit model and backward stepwise regression method. Finally, establish the evaluation system and put forward the adjustment of credit management strategy.

\section{Model hypothesis}

Table 1. Model hypothesis

\begin{tabular}{|l|l|}
\hline$W_{i}$ & Corporate weight \\
\hline$P_{i}$ & Stock closing price for the week \\
\hline$Q_{i}$ & Total stock \\
\hline$P$ & Average share price \\
\hline$S T L$ & Average short-term industry liabilities \\
\hline$L T L$ & Average industry long-term debt per share \\
\hline$r_{Q}$ & Average industry earnings per share \\
\hline$D$ & Default threshold \\
\hline $\mathrm{V}$ & Average asset value of the industry \\
\hline$\sigma_{V}$ & Average earnings per share \\
\hline$D D$ & Default distance \\
\hline$J P D$ & Joint probability of default \\
\hline$p$ & Default probability \\
\hline$r_{\mathrm{k}}$ & Interest rate on bank loans to enterprises \\
\hline
\end{tabular}

\section{Models}

\subsection{Analysis and problem one solving}

Data preprocessing: we analyze and sort out the data given in Annex I, delete and utilize the invalid invoice, and 
establish a scoring system for the invalidation of bills between enterprises.

Sample selection: in the analysis of sales invoice and entry invoice data, we try to learn more from the financial statements, and consider that the development of small and medium-sized enterprises is uncertain, poor financing and other conditions are difficult to find out. This paper decides to replace the management level of a small microenterprise with industry average. Therefore, the text selected five sample industries: machinery and equipment industry, construction industry, metal non-metallic industry, transport warehousing industry and wholesale and retail industry, and 20 sample companies.

\subsection{Model building solution}

Table 2. Default distance and probability of default

\begin{tabular}{|c|c|c|c|c|c|c|c|c|}
\hline $\begin{array}{l}\text { Serial } \\
\text { number }\end{array}$ & $\begin{array}{l}\text { Industry } \\
\text { name }\end{array}$ & $\begin{array}{l}\text { Weighted share } \\
\text { price average } \\
\text { Percent }\end{array}$ & $\begin{array}{l}\text { Volatility of } \\
\text { stock returns } \\
\sigma \mathrm{s}\end{array}$ & $\begin{array}{l}\text { Default } \\
\text { threshold }\end{array}$ & $\begin{array}{l}\text { Value of } \\
\text { assets per } \\
\text { share }\end{array}$ & $\begin{array}{l}\text { Asset } \\
\text { return } \\
\text { volatility } \\
\sigma v \\
\end{array}$ & $\begin{array}{l}\text { Default } \\
\text { distance } \\
\text { DD }\end{array}$ & $\begin{array}{l}\text { Default } \\
\text { probability } \\
\text { p / \% }\end{array}$ \\
\hline 1 & $\begin{array}{l}\text { Mechanical } \\
\text { equipment }\end{array}$ & 8.38 & 0.37 & 7.56 & 14.26 & 0.17 & 3.78 & 0.000167 \\
\hline 2 & Construction & 8.97 & 0.35 & 16.33 & 25.72 & 0.13 & 3.55 & 0.000192 \\
\hline 3 & $\begin{array}{l}\text { Non-metallic } \\
\text { metal }\end{array}$ & 14.56 & 0.33 & 7.89 & 21.88 & 0.16 & 3.76 & 0.000093 \\
\hline 4 & $\begin{array}{l}\text { Transport } \\
\text { warehousing }\end{array}$ & 3.83 & 0.21 & 1.46 & 4.87 & 0.34 & 5.86 & 0.000007 \\
\hline 5 & $\begin{array}{l}\text { Wholesale } \\
\text { and retail }\end{array}$ & 13.31 & 0.25 & 11.58 & 23.53 & 0.21 & 4.43 & 0.000012 \\
\hline
\end{tabular}

Optimized allocation of funds model as follows:

$r_{k}=r_{b}+p_{k} \cdot L G D=r_{b}+C S_{k}$

According to the definition of comprehensive weight, the constraints are as follows:

$\sum_{k=1}^{m} w_{k}=1$

Use to indicate whether the first industry is in default, if default, otherwise, now to calculate the bank's overall rate of return in the first default state, there are:

$r_{p s}=\sum_{q=1}^{m} w_{q}\left\{[1-f(d, q)] r_{q}-f(d, q) L G D\right\}$

Among them, if the first industry does not default, then, and. That is, the bank to the first industry to obtain the rate of return. If the default, and, and the bank on the first industry loss.

$f(d, q)=01-f(d, q)=11 q r_{q} f(d, q)=11-f(d, q)=0$ q $L G D$

The expected rate of return on banks:

$E\left(r_{p}\right)=\sum_{d=1}^{2^{m}} J P D_{d} * r_{p s}$

$E\left(r_{p}\right) 2^{m} J P D_{q}$

Among them, the expected rate of return of the bank in the default state is the joint probability of the d default state.

$\operatorname{var}\left(r_{p}\right)=\sum_{s=1}^{2^{m}} J P D_{q}\left[r_{p s}-E\left(r_{p}\right)\right]^{2}$

$\operatorname{std}\left(r_{p}\right)=\left[\operatorname{var}\left(r_{p}\right)\right]^{\frac{1}{2}}$

$\operatorname{var}\left(r_{p}\right) \operatorname{std}\left(r_{p}\right)$

Among them, the variance of the bank's overall rate of return and the standard deviation of the bank's overall rate 
of return.

$C V=\frac{s t d\left(r_{p}\right)}{E\left(r_{p}\right)}$

Among them, for the bank overall rate of return difference coefficient.

Table 3. Mean, variance and difference coefficient of bank's overall credit fund return

\begin{tabular}{|l|l|l|l|}
\hline Serial number & Indicator name & Equal Weight Credit Fund & Optimal Weighted Credit Funds \\
\hline 1 & Average return rate $E\left(r_{a}\right)$ & 0.0458 & 0.054 \\
\hline 2 & $\begin{array}{l}\text { Rate of return standard devia- } \\
\text { tion }\end{array}$ std $\left(r_{a}\right)$ & 0.0538 & 0.0466 \\
\hline 3 & Difference coefficient $C V$ & 1.1735 & 0.8633 \\
\hline
\end{tabular}

Table 4. Initial loan weight and optimal loan weight

\begin{tabular}{|l|l|l|l|}
\hline$(\mathbf{1})$ & $(\mathbf{2})$ & $(\mathbf{3})$ & $(\mathbf{4})$ \\
\hline Serial number & Industry name & Initial weight $w_{i 0}$ & Optimal weight $W_{2 \mathrm{i}}$ \\
\hline 1 & Mechanical equipment & 0.2 & 0.2738 \\
\hline 2 & Construction & 0.2 & 0.0358 \\
\hline 3 & Non-metallic metal & 0.2 & 0.3558 \\
\hline 4 & Transport warehousing & 0.2 & 0.2915 \\
\hline 5 & Wholesale and retail & 0.2 & 0.0432 \\
\hline
\end{tabular}

Among them, it is the loan weight of the bank to m industries as a whole, the difference coefficient of the bank's overall rate of return, the expected rate of return of the bank in the state of default, and the target rate of return.

\section{Conclusion}

Using the KMV model and the normal Copula function to calculate the industry default distance and joint default probability, considering the bank expected rate of return, enterprise default linkage probability and other factors, establish the optimal allocation model, to obtain the industry loan funds optimal weight ratio; at the same time, the credit rating of enterprises, the number of scrap tickets and other quantitative analysis, finally concluded that banks can make more loans to metal non-metallic, transport warehousing, machinery and equipment three industries, in terms of term and interest rates can also be given a greater degree of preferential treatment, at the same time for the construction industry, wholesale and retail, individual businesses can be assessed, according to the actual situation to lend.

\section{References}

1. Chi G, Zhang Y, Shi B. The debt rating for small enterprises based on Probit regression. Journal of Management Sciences in China 2016; (6): 136 - 156.

2. Cao Y, Li M, Li G, et al. Bank loan portfolio optimization model between industries based on joint probabilities of default states. Journal of Systems \& Management 2018; 27(5): 881 - 894.

3. Yu D, Li X. Credit risk assessment of small and medium enterprises under supply chain finance model - Taking electronic manufacturing industry as an example (in Chinese). Credit Reference 2019; 37(10): $72-77$. 